OAK RIDGE

ORNL/TM-2001/64

NATIONAL LABORATORY

MANAGED BY UT-BATTELLE

FOR THE DEPARTMENT OF ENERGY

\title{
Compositions, Functions, and Testing of Friction Brake Materials and Their Additives
}

September 2001 


\section{DOCUMENT}

\section{AVAILABILITY}

Reports produced after January 1,1996, are generally available free via the U.S. Department of Energy (DOE) Information Bridge.

Web site http://www.osti.gov/bridge

Reports produced before January 1,1996, may be purchased by members of the public from the following source.

National Technical Information Service

5285 Port Royal Road

Springfield, VA 22161

Telephone 703-605-6000 (1-800-553-6847)

TDD 703-487-4639

Fax 703-605-6900

E-mail info@ntis.fedworld.gov

Web site http://www.ntis.gov/support/ordernowabout.htm

'Reports are available to DOE employees, DOE contractors, Energy Technology Data Exchange (ETDE) representatives, and International Nuclear Information System (INIS) representatives from the following source.

Office of Scientific and Technical Information

P.O. Box 62

Oak Ridge, TN 37831

Telephone 865-576-8401

Fax 865-576-5728

E-mail reports@adonis.osti.gov

Web site http://www.osti.gov/contact.html

This report was prepared as an account of work sponsored by an agency of the United States Government. Neither the United States Government nor any agency thereof, nor any of their employees, makes any warranty, express or implied, or assumes any legal liability or responsibility for the accuracy, completeness, or usefulness of any information, apparatus, product, or process disclosed, or represents that its use would not infringe privately owned rights. Reference herein to any specific commercial product, process, or service by trade name, trademark, manufacturer, or otherwise, does not necessarily constitute or imply its endorsement, recommendation, or favoring by the United States Government or any agency thereof. The views and opinions of authors expressed herein do not necessarily state or reflect those of the United States Government or any agency thereof. 


\section{Metals and Ceramics Division}

\section{Compositions, Functions, and Testing of Friction Brake Materials and Their Additives}

Peter J. Blau

August 2001

Prepared for

U.S. Department of Energy, Assistant Secretary for Energy Efficiency and Renewable Energy, Office of Transportation Technologies

Prepared by

OAK RIDGE NATIONAL LABORATORY

Oak Ridge, Tennessee 3783 1-6285 managed by

UT-B ATTELLE, LLC

for the

U.S. DEPARTMENT OF ENERGY

Under contract DE-AC05-00OR22725 
.

\author{
.
}




\section{Preface}

This report was prepared as an information resource for the development of advanced brake materials for heavy vehicles. This research is sponsored by the U.S. Department of Energy, Office of Transportation Technologies. It is part of an initiative aimed at reducing the running resistance while improving the safety of on-highway heavy trucks. Selected information on aircraft brake materials was included for comparison purposes. Data in this report have been compiled from a variety of commercial and non-commercial sources. The validity of the data in this compilation is the responsibility of the originators, and information contained herein should be used mainly as a guide and for the sake of comparison. Normally, IS0 units are used in ORNL reports, but in this case, the units have been reported in the measurement systems that were used in the original references. They reflect the diversity in current preferences for units of measure in the commercial brakes industry.

In addition to Dr. Sidney Diamond, DOE, Office of Transportation Materials, and Dr. Phil Sklad, Metals and Ceramics Division, ORNL, I would like to thank those who reviewed the drafts of this document and made useful suggestions for improvement. In particular, I'd like to thank Rena Hecht Basch, Dr., Sr. Technical Specialist, Ford Research Laboratory, Safety Research and Development Department, for her practical comments.

Peter J. Blau

Metals and Ceramics Division

Oak Ridge National Laboratory 



\section{Contents}

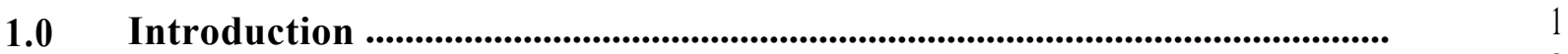

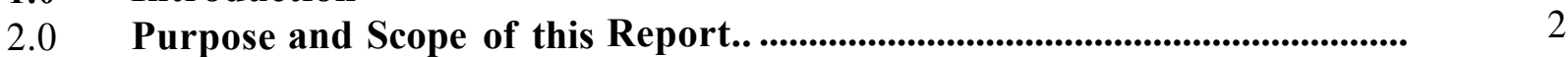

3.0 Brake Materials and Additive Functionality ................................................. 2

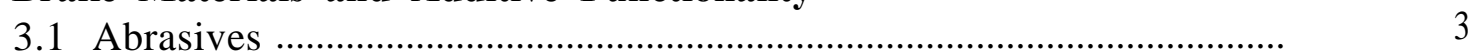

3.2 Friction to Producers/Modifiers ............................................................. 3

3.3 Fillers, Reinforcements, and Miscellaneous........................................... 5

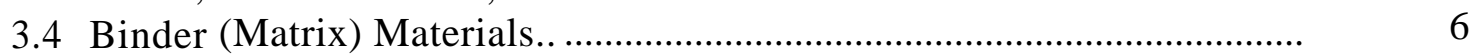

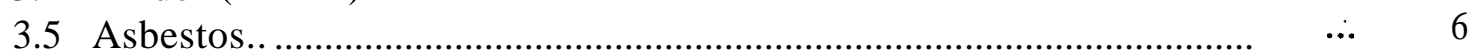

3.5.1 Wear of Asbestos Materials ......................................................... 6

3.5.2 Regulations and the Current Use of Asbestos in Brakes.................. 7

3.5.3 Possible Replacements for Asbestos in Brakes.............................. 7

4.0 Brake Friction Designations and Typical Compositions .................................. 8

4.1 Edge Codes ....................................................................................

4.2 Friction Brake Compositions for Aircraft and Ground Vehicles ................. 9

4.2.1 Aircraft Brake Formulations …....................................................

4.2.2 Automotive Brake Pad Formulations............................................. 11

4.2.3 Passenger Car and Truck.Brake Disc and Drum Materials.............. 16

5.0 Brake Material Test Methods and Apparatus.. .................................................. 18

5.1 The FAST Machine ............................................................................ 19

5.2 The Chase Machine ........................................................................... 19

5.3 Other Sub-Scale Testing Machines ........................................................ 20

5.4 Inertial Dynamometers and FMVSS Tests …........................................ 20

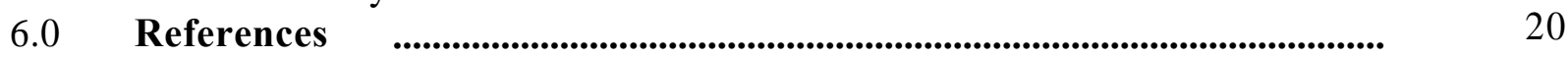

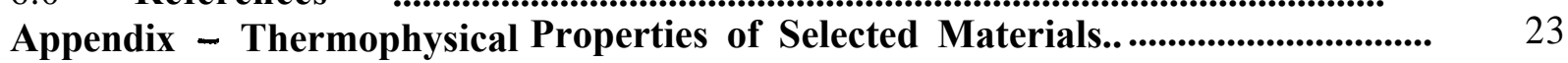





\subsection{Introduction}

The purpose of friction brakes is to decelerate a vehicle by transforming the kinetic energy of the vehicle to heat, via friction, and dissipating that heat to the surroundings. As a part of a commercial truck or automobile, brake materials have additional requirements, like resistance to corrosion, light weight, long life, low noise, stable friction, low wear rate, and acceptable cost versus performance. There are two common types of friction brakes - drum/shoe brakes and disk/pad brakes. The design of the brakes affects heat flow, reliability, noise characteristics, and ease of maintenance.

History records the use of many kinds of materials for brakes ('friction materials'). For example, wagon brakes used wood and leather. In fact, many current brake materials still contain organic-based materials, like polymers and plant fibers. Emerging. railroad technology in the 1800's required brake materials to perform under high loads and speeds. Friction experiments were conducted with iron brake shoes in the 1870's (see, for example, Fig. 1).

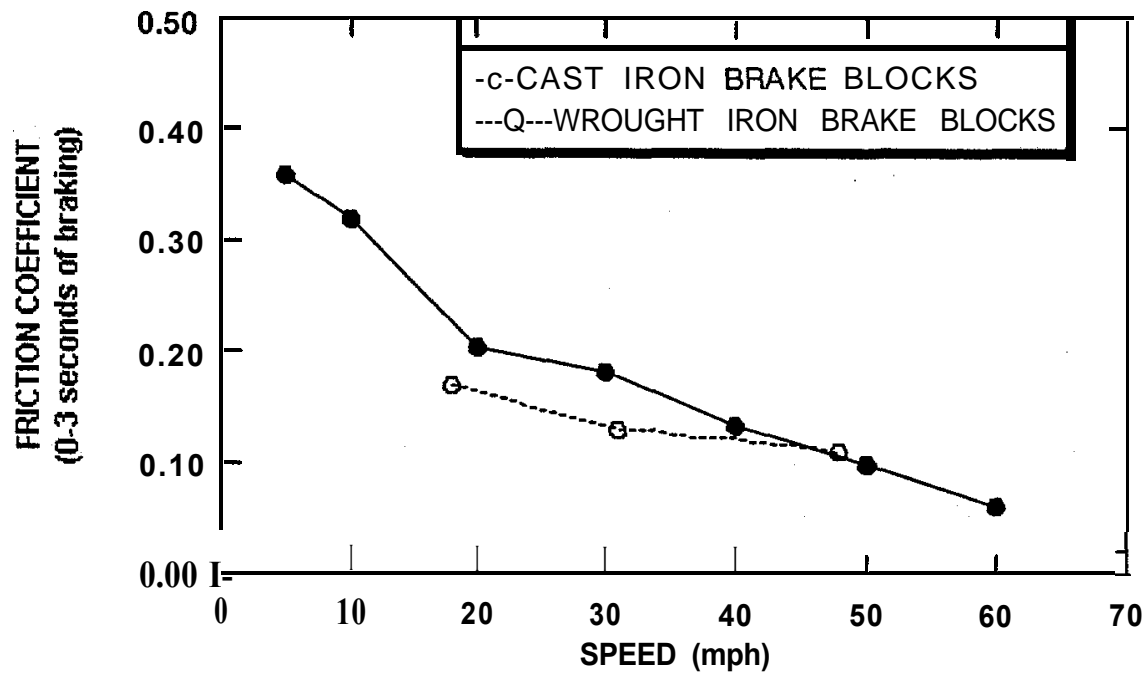

Figure 1. Test results from the work of Captain D. Galton (1878) using a special railroad wheel brake simulator and steel test wheels.

In order to achieve the properties required of brakes, most brake materials are not composed of single elements or compounds, but rather are composites of many materials. More than 2000 different materials and their variants are now used in commercial brake components [Weintraub (1998)].

According to Nicholson(1995), Herbert Frood is credited with inventing the first brake lining materials in 1897. It was a cotton-based material impregnated with bitumen solution and was used for wagon wheels as well as early automobiles. His invention led to the founding of the Ferodo Company, a firm that still supplies brake materials today. The first brake lining materials were woven, but in the 1920's these were replaced with molded materials that contained crysotile asbestos fibers, a plentiful mineral. Resin-bonded metallic linings were introduced in the 1950's, and by the 1960's so-called 'semi-mets' were developed. These contain a higher amount of metal additives. Table 1 from Nicholson (1995) lists some common brake materials. 
Table 1. Historical Compositions of Automotive Friction Brake Materials

\begin{tabular}{|c|c|c|}
\hline Material Description & Application(s) & $\begin{array}{c}\begin{array}{c}\text { Approximate } \\
\text { Year }\end{array} \\
\end{array}$ \\
\hline Cast iron on steel & railroad car brake blocks and tires & prior to 1870 's \\
\hline $\begin{array}{l}\text { Hair or cotton belting (limited by charring at about } \\
300^{\circ} \mathrm{F} \text { ) }\end{array}$ & $\begin{array}{l}\text { wagon wheels and early } \\
\text { automobiles }\end{array}$ & ca. 1897 \\
\hline $\begin{array}{l}\text { Woven asbestos with brass and other wires for } \\
\text { increased strength and performance }\end{array}$ & automobiles and trucks & ca. 1908 \\
\hline $\begin{array}{l}\text { Molded linings with shorter chrysotile fibers, brass } \\
\text { particles, and low-ash bituminous coal }\end{array}$ & “، “ “6 & ca. 1926 \\
\hline $\begin{array}{l}\text { Dry-mix molded material to replace cast iron brake } \\
\text { blocks that produced metallic dust that shorted } \\
\text { electric train rails }\end{array}$ & London underground & ca. 1930 \\
\hline $\begin{array}{l}\text { Flexible resin binders developed along with more } \\
\text { complex formulations }\end{array}$ & brake drum linings & 1930’s \\
\hline Resin-bonded metallic brake linings & industrial and aircraft applications & 1950's \\
\hline $\begin{array}{l}\text { Glass fibers, mineral fibers, metal fibers, carbon and } \\
\text { synthetic fibers to provide semi-metallics with } \\
\text { higher performance than asbestos (beginning of } \\
\text { safety issues with asbestos) }\end{array}$ & automotive and trucks & 1960's \\
\hline Non-asbestos (fiberglas) materials & $\begin{array}{l}\text { brake drums on original equipment } \\
\text { cars }\end{array}$ & $1980^{\circ} \mathrm{s}$ \\
\hline Suggested use of carbon fibers & automotive brakes & 1991 \\
\hline
\end{tabular}

\subsection{Purpose and Scope of this Report}

The purpose of this report is to present a survey of commercial brake materials and additives, and to indicate their typical properties and functions, especially as regards their use in heavy trucks. Most truck pad and shoe materials described here were designed to wear against cast iron. Brake material test methods are also briefly described. This report does not address issues associated with the fabrication and manufacturing of brake materials. Since there are literally thousands of brake material additives, and their combinations are nearly limitless, it is impractical to list them all here. Rather, an attempt has been made to capture the primary constituents and their functions. An Appendix contains thermo-physical properties of some current and potential brake materials.

\subsection{Brake Materials and Additive Functionality}

Brake pad and shoe additives serve a variety of functions. Even a difference of a percent or two of additive concentration can affect performance, so composition control is important. This report lists additive materials by function. Information is referenced using the first author's name and year. If the information is from a handbook or commercial source, the reference will be listed by publisher or by company name. According to Nicholson (1995), it is conventional to list compositions of brake additives in volume percent, but not all authors do so.

One can group brake materials and additives based on their expected functions as follows: 

Abrasives
Friction Modifiers
Fillers and Reinforcements
Binder Materials

There is a little ambiguity in this categorization. Some of the additives can be placed into more than one category since they fulfill several functions. Consequently, there are some unavoidable overlaps in the tabular listings. In addition to the basic brake materials, some porosity (5-10\% or more) is normally present.

To analyze the role of additives in friction and wear control, it is insufficient to simply know their composition, since their form, distribution, and particle size can affect friction and wear behavior. For example, rounded beads of a hard, abrasive material can have a different effect than angular grits on the formation and stability of the friction-induced surface films that control stopping behavior.

Asbestos has had a historical role as a brake additive. Section 3.5 is devoted to it.

\section{$\underline{3.1}$ Abrasives}

Abrasives help maintain the cleanliness of mating surfaces and control the build-up of friction films. They also increase friction, particularly when initiating'a stop (i.e., they increase "bite").

\begin{tabular}{|l|l|l|}
\hline \multicolumn{1}{|c|}{ Material } & \multicolumn{1}{|c|}{ Description /Comment } & \multicolumn{1}{c|}{ Reference(s) } \\
\hline \hline aluminum oxide & $\begin{array}{l}\text { (1) hydrated form added as a polishing agent and for } \\
\text { wear resistance, but can produce fade, (2) anhydrous } \\
\text { form is still more abrasive, (3) fused is very hard and is } \\
\text { the most abrasive form }\end{array}$ & Nicholson (1995) \\
\hline iron oxides & $\begin{array}{l}\text { hematite }\left(\mathrm{Fe}_{2} \mathrm{O}_{3}\right) \text { can act as a mild abrasive; magnetite } \\
\left(\mathrm{Fe}_{3} \mathrm{O}_{4}\right) \text { also mildly abrasive }\end{array}$ & Nicholson (1995) \\
\hline quartz & crushed mineral particles $\left(\mathrm{SiO}_{2}\right)$ & Eriksson (2000) \\
\hline silica & may be natural or synthetically-produced $\left(\mathrm{SiO}_{2}\right)$ & Hooton (1969) \\
\hline zirconium silicate & $(\mathrm{ZrSi04})$ & Jang (2000) \\
\hline
\end{tabular}

\subsection{Friction Producers / Modifiers}

These materials lubricate, raise the friction, or react with oxygen to help control interfacial films.

\begin{tabular}{|l|l|l|}
\hline \multicolumn{1}{|c|}{ Material } & \multicolumn{1}{|c|}{ Description / Comment } & \multicolumn{1}{c|}{ Reference } \\
\hline \hline antimony trisulfide & $\begin{array}{l}\text { solid lubricant added to enhance frictional stability; } \\
\text { lubricates }>450^{\circ} \mathrm{C}_{;} \mathrm{Sb}_{2} \mathrm{~S}_{3} \text { is potentially toxic }\end{array}$ & $\begin{array}{l}\text { Jang }(2000), \text { Nicholson } \\
(1995)\end{array}$ \\
\hline Brass & $\begin{array}{l}\text { typ. } 62 \% \mathrm{Cu}-38 \% \mathrm{Zn} ; \text { sometimes used as chips or } \\
\text { machine shop cutting swarf, said to improve wet friction } \\
\text { and recovery, common additive }\end{array}$ & Nicholson (1995) \\
\hline
\end{tabular}




\begin{tabular}{|c|c|c|}
\hline Material & Description / Comment & Reference \\
\hline carbon (graphite) & $\begin{array}{l}\text { cheap and widely-used; but there are many forms and } \\
\text { sources, some of which can contain abrasive } \\
\text { contaminants; burns in air at }>700^{\circ} \mathrm{C} \text {, friction level is } \\
\text { affected by moisture and structure }\end{array}$ & $\begin{array}{l}\text { Spurr (1972), Nicholson } \\
\text { (1995) }\end{array}$ \\
\hline ceramic "microspheres" & $\begin{array}{l}\text { special product consisting of alumina-silica with minor } \\
\text { iron or titanium oxides; size IO-350 ym, low-density } \\
\text { filler said to reduce rotor wear and control friction; claim } \\
\text { to also absorb rotor dust; } 5-10 \% \text { vol. loading typ. } \\
\end{array}$ & \begin{tabular}{|l} 
PQ Corporation (1993) \\
\end{tabular} \\
\hline copper & $\begin{array}{l}\text { used as a powder to control heat transport but can } \\
\text { cause excessive cast iron wear }\end{array}$ & Nicholson (1995) \\
\hline "friction dust" & $\begin{array}{l}\text { commonly consists of processed cashew resin, may } \\
\text { have a rubber base; some additives used to reduce } \\
\text { spontaneous combustion or help particle dispersion. }\end{array}$ & Nicholson (1995) \\
\hline "ffriction powder' & $\begin{array}{l}\text { may consist of Fe sponge, e.g. for semi-metallic brake } \\
\text { pads; a number of different particle grades (sizes) are } \\
\text { available depending on requirements for surface area, } \\
\text { light-medium-heavy duty vehicle applications. }\end{array}$ & Hoegenaes (1990) \\
\hline lead oxide & $\begin{array}{l}\text { PbO has been used as a friction modifier, but has } \\
\text { toxicity concerns }\end{array}$ & Nicholson (1995) \\
\hline metals - fluxing compounds & $\begin{array}{l}\mathrm{Pb}, \mathrm{Sb}, \mathrm{Bi}, \mathrm{Mo} \text {, as fluxing compounds serve as oxygen } \\
\text { getters to stabilize friction-induced films and help to } \\
\text { keep them from getting too thick }\end{array}$ & Hooton (1969) \\
\hline metal oxides - various & $\begin{array}{l}\text { magnetite }\left(\mathrm{Fe}_{3} \mathrm{O}_{4}\right) \text { improves cold friction; } \mathrm{ZnO} \text { lubricates } \\
\text { but can cause drum polishing; } \mathrm{Cr}_{2} \mathrm{O}_{3} \text { raises friction }\end{array}$ & Nicholson (1995) \\
\hline metal sulfides - various & $\begin{array}{l}\mathrm{Cu}_{2} \mathrm{~S}_{1} \mathrm{Sb}_{2} \mathrm{~S}_{3}, \mathrm{PbS} \text {; studies show the effect of additives } \\
\text { on disc brake pads with and without metal fibers; } \\
\text { modify and stabilize the friction coefficient; highest } \mu \text { for } \\
\mathrm{Sb}(0.47-0.49) \text {, next } \mathrm{PbS}(0.40-0.47) \text {, most variable for } \\
\mathrm{Cu}(0.36-0.52) \text { - wear worst for } \mathrm{Cu}-\mathrm{S}\end{array}$ & $\begin{array}{l}\text { Gudmand-Hoyer, et al. } \\
\text { (1999) }\end{array}$ \\
\hline metal sulfides - various & $\begin{array}{l}\text { PbS - soft solid lubricant additive (2-8\% by wt.) with } \\
\text { thermal decomposition products also lubricating, said to } \\
\text { reduce pad and rotor wear and reduce noise; MoS } 2 \\
\text { adheres more readily to metal surfaces than graphite } \\
\text { and has broad temp. range ( } 3-8 \% \text { by wt typ.); ZnS is a } \\
\text { low cost solid lubricant recommended for high loads } \\
\text { and temperatures (5-10\% by wt. typ.); metal sulfide } \\
\text { mixtures are also used }\end{array}$ & BBU (1993) \\
\hline $\begin{array}{l}\text { mineral fillers (mullite, } \\
\text { kyanite, sillimanite, alumina, } \\
\text { crystalline silica) }\end{array}$ & $\begin{array}{l}\text { mullite, kyanite, sillimanite are friable and help control } \\
\text { frictional behavior while also controlling wear on the } \\
\text { counterface due to their own fracturing }\end{array}$ & Hooton ( 969) \\
\hline mineral fillers & $\begin{array}{l}\mu \text { is roughly proportional to Mohs hardness; too much } \\
\text { mineral filler tends to wear the counter-face }\end{array}$ & Spurr (1972) \\
\hline molybdenum disulfide & $\left(\mathrm{MoS}_{2}\right)$, a typical layer-lattice-type lubricant & Spurr (1972) \\
\hline petroleum coke & low-cost, can lower friction, low ash & Nicholson (1995) \\
\hline
\end{tabular}




\section{$\underline{3.3 \text { Fillers, Reinforcements, and Miscellaneous }}$}

Fillers are used to maintain the overall composition of the friction material, and some have other functions as well. They can be metals, alloys, ceramics, or organic materials.

\begin{tabular}{|c|c|c|}
\hline Material & Description / Comment & Reference(s) \\
\hline anti-oxidants & $\begin{array}{l}\text { help to maintain the proper oxide film thickness on } \\
\text { aircraft brakes - too much oxide leads to unstable } \\
\text { friction (high at low speeds) and thick films that can } \\
\text { wear off too readily; graphite is a common one in metal- } \\
\text { ceramic composite brakes }\end{array}$ & Hooton (1969) \\
\hline asbestos & most common filler in early brake materials (see 3.5) & $\begin{array}{l}\text { Spurr (1972), Rhee } \\
\text { (1974), Nicholson } \\
\text { (1995) } \\
\end{array}$ \\
\hline barium sulfate ("barytes") & $\begin{array}{l}\left(\mathrm{BaSO}_{4}\right) \text { basically inert, but increases density and may } \\
\text { aid in wear resistance, stable at high temperature }\end{array}$ & Nicholson (1995) \\
\hline calcium carbonate & $\begin{array}{l}\mathrm{CaCO}_{3} \text { is a lower cost alternative to barytes, but not } \\
\text { quite as stable at high temperatures }\end{array}$ & Nicholson (1995) \\
\hline $\begin{array}{l}\text { cashew nut shell oil (se } \\
\text { discussion below) }\end{array}$ & $\begin{array}{l}\text { proves resilience in the binder system and reduces } \\
\text { brake noise (see also "friction dust" in 3.2) }\end{array}$ & Nicholson (1995) \\
\hline cotton & reinforcing fiber for the matrix & Spurr (1972) \\
\hline fibers - mixed oxide & $\begin{array}{l}\text { reinforcement fibers, produced from a base slag } \\
\text { mineral wool, can contain, for example, a mixture of } \\
\text { silica ( } 40-50 \text { wt } \%) \text {, alumina ( } 5-15 \text { wt. } \%) \text {, calcia ( } 34-42 \\
\text { wt } \%) \text {, magnesia (3-10 wt\%), and other inorganics (0-7 } \\
\text { wt\%); function is to control fade and increase braking } \\
\text { effectiveness }\end{array}$ & ploss (no year) \\
\hline lime & $\begin{array}{l}\mathrm{Ca}(\mathrm{OH})_{2} \text { is used to avoid corrosion in Fe-additives, } \\
\text { helps in processing, helps raise fade temperatures }\end{array}$ & Nicholson (1995) \\
\hline potassium titanate & $\begin{array}{l}\text { inert filler material; also, an insulator and structural } \\
\text { participant to replace the role of asbestos }\end{array}$ & Jang (2000) \\
\hline rubber - diene, nitrile & $\begin{array}{l}\text { used as stabilizers to promote cross-linking and } \mathrm{K} \text {. } \\
\text { increase wear resistance in polymer composite brake } \\
\text { materials containing asbestos fibers; rubber also } \\
\text { modifies the compressibility (modulus/stiffness) }\end{array}$ & C. Gong et al. (1985) \\
\hline rubber scrap & $\begin{array}{l}\text { ground up tires ("tire peels"), decreases cost, must not } \\
\text { contain road dirt }\end{array}$ & Nicholson (1995) \\
\hline sea coal & $\begin{array}{l}\text { general low-cost particulate filler, may contain harmful } \\
\text { ash; not good for high temperatures }\end{array}$ & Nicholson (1995) \\
\hline zinc oxide & $\begin{array}{l}\text { ZnO imparts some wear resistance, but can polish } \\
\text { drums }\end{array}$ & Nicholson (1995) \\
\hline
\end{tabular}

Cashew-containing friction dust is said to have the ability to absorb the heat created by friction while retaining braking efficiency. It is a major export product of India and the Asian subcontinent. The supposed advantage of cashew resin, compared with plain phenolic resin, is that it produces a softer material which is more efficient for wear when the brakes are relatively cold, as in temperatures generated by lower speed automobiles. Cashew friction dust is a granular, free flowing polymerised resin derived from Cashew Nut Shell Liquid (CNSL). The main component in processed cashew nutshell liquid (CNSL) is cardanol, a naturally occurring, 
meta-substituted alkenyl phenol similar to nonylphenol. Cardanol is hydrophobic in nature and remains flexible and liquid at very low temperatures.

\section{$\underline{3.4 \text { Binder (Matrix) Materials }}$}

Typical binder materials are phenolic resins in the case of automotive and truck pads. There are three common types of aircraft friction brake marterials: (1) sintered metal (most widely used), (2) carbon-carbon, and (3) organic materials. Fe-based metallics tend to have a lower friction response than $\mathrm{Cu}$-based matrix materials [Ref.: Tatarzycki and Webb (1992)]

\begin{tabular}{|c|c|c|}
\hline Material & Description / Comment & Reference(s) \\
\hline phenolic resin & $\begin{array}{l}\text { common binder; too little - material weakness; if too } \\
\text { much is used, there is a friction drop-off at high } \\
\text { temperatures; the degree of polymer cross-linking } \\
\text { affects behavior }\end{array}$ & Spurr (1972) \\
\hline metallic alloys of $\mathrm{Cu}, \mathrm{Fe}, \mathrm{Ni}$ & aircraft brake matrix materials* & $\begin{array}{l}\text { Hooton (1969); Tatarzycki } \\
\text { (1992) }\end{array}$ \\
\hline modified resins & $\begin{array}{l}\text { a variety of modified resins is available; modifications } \\
\text { to alter bonding characteristics and temperature } \\
\text { resistance include cresol, epoxy, cashew, PVB, } \\
\text { rubber, linseed oil, and boron }\end{array}$ & Borden (1994) \\
\hline
\end{tabular}

\section{$\underline{3.5 \text { Asbestos }}$}

Asbestos is hydrated magnesium silicate $\mathrm{Mg}_{3} \mathrm{Si}_{2} \mathrm{O}_{5}(\mathrm{OH})_{4}$. When it is used, the content of asbestos in vehicle brakes varies between about 30-70\%. According to Nicholson (1995), the positive characteristics of asbestos are: (1) asbestos is thermally stable to $500^{\circ} \mathrm{C}$ above which it produces silicates, (2) asbestos helps regenerate the friction surface during use, (3) silicates produced by asbestos are harder and more abrasive that asbestos, (4) asbestos insulates thermally, (5) it processes well, (6) it wears well, (7) it is strong yet flexible, and (8) asbestos is available at reasonable cost. The fibrous character remains in tact until about $1400^{\circ} \mathrm{C}$.

According to Spurr (1972), asbestos becomes dehydroxylated at high temperatures. It tends to transform to forsterite and silica above $810^{\circ} \mathrm{C}$. The wear debris contains forsterite or amorphous material. The kinetic friction coefficient $\left(\mu_{\mathrm{k}}\right)$ of asbestos against clean iron is $\sim 0.80$. The type of asbestos used is important because of differences in cost, properties, and processing. Chrysotile is normally used but other asbestos minerals, amosite and crocodolite, may be used. Chrysotile makes up approximately $90 \%-95 \%$ of all asbestos contained in buildings in the United States [Ref. University of Minnesota Asbestos and Lead Management Group, Internet URL, http://www.dehs.umn.edu/asbestos/]. Three other types (Anthophyllite, Tremolite, and Actinolite) are rarer and found mainly as minor contaminants along with other minerals.

\subsubsection{Wear of Asbestos Materials}

The wear rate of asbestos brakes was studied and reviewed by S. K. Rhee of Bendix Corporation. The wear rate of an asbestos-reinforced lining, in drum-type tests, was investigated (1970, 1971, 1974), and the following general relationship was used to model the process (1970): 


$$
\mathrm{AW}=\alpha P^{a} V^{b} t^{c}
$$

where AW = wear loss (grams), $P=$ normal pressure (psi), $V=\operatorname{sliding}$ speed (r-pm), and $t=$ sliding time (min.). Proportionality factor a depends on testing geometry. Values of exponents a, $b$, and $\mathrm{c}$ are material pair-related. The wear rate of asbestos-containing friction materials is reported to be about constant up to $450^{\circ} \mathrm{F}\left(232^{\circ} \mathrm{C}\right)$, after which it increased exponentially.

\subsubsection{Regulations and the Current Use of Asbestos in Brakes}

Medical research showed that asbestos fibers can lodge in the lungs and induce adverse respiratory conditions. In 1986, the Environmental Protection Agency announced a proposed ban on asbestos. The ban would have required all new vehicles to have non-asbestos brakes by September 1993, and the aftermarket would have had until 1996 to convert to non-asbestos. The EPA's proposed ban was overturned in federal court, but it resulted in a major shift away from asbestos by most friction material suppliers and vehicle manufacturers. Ford was still using asbestos linings as recently as 1993 on its Crown Victoria model, but has since discontinued using them. A few high-end imports such as Land Rover are the only original equipment applications that still use asbestos.

Asbestos brake products are still used in the aftermarket despite the fact many people think asbestos was replaced by non-asbestos organics years ago. In 1996, MarketScope research (MarketScope, is a division of Babcox Publications, Inc.) reported that asbestos linings were still being installed on $9.5 \%$ of the vehicles'serviced by its readers. That is a significant percentage of the total brake market, considering that many people believe that asbestos is no longer even available. Asbestos is still used because it's an economical fiber for low temperature brake applications, but it is gradually being phased out for the aforementioned reasons. [Ref. to website URL <http://www.babcox.com/cm/cm99628.htm>]

Mandatory OSHA requirements concerning asbestos in brakes can be found in OSHA Standard 1910.1001, Appendix F "Work practices and engineering controls for automotive brake and clutch inspection, disassembly, repair and assembly"; Subpart Number: Z "Toxic and Hazardous Substances.

"This mandatory appendix specifies engineering controls and work practices that must be implemented by the employer during automotive brake and clutch inspection, disassembly, repair, and assembly operations."

\subsubsection{Possible Replacements for Asbestos in Brakes}

Nicholson (1995) lists the following replacement materials for asbestos. None is exactly like asbestos but they offer some similar performance characteristics: wollastonite (calcium silicate), vermiculite (hydrated calcium aluminum silicate), mica (aluminum silicate), basalt fiber, rockwool (blast furnace slag or basalt), Fiberfrax ${ }^{\circledR}$ ceramic fiber, polyacrylonitrile (PAN), polyester, chopped glass fiber, and aramid fibers. 


\subsection{Brake Friction Designations and Typical Compositions}

According to Anderson (1980), friction coefficients for brake material pairs span a range of 0.07 to 0.7 , but practically, most vehicles operate within a narrower range. Typical values range from 'about $0.3-0.6$ in friction coefficient. Anderson lists six classes of friction materials depending on operational capabilities. The higher the class number, the more severe the operating conditions. Materials must be formulated to withstand the energy dissipation requirements of use. Classes III and IV used in trucks, for example, must withstand 3-4 MPa of pressure and speeds of $35-50 \mathrm{~m} / \mathrm{s}$, respectively. The counterface temperatures can reach up to $600-800^{\circ} \mathrm{C}$. This temperature range is at least $150^{\circ} \mathrm{C}$ above the estimated use temperature for aluminum metal matrix composites [see Section 4.2.3.2].

\section{$\underline{4.1 \text { Edge Codes }}$}

The Society of Automotive Engineers (SAE) developed a Friction Identification System for Brake Linings and Brake Blocks (SAE Recommended Practice SAE J866a). Consisting of two letters, these so-called 'edge codes' were stamped on the sides of commercial brake replacement linings and blocks as a guide for motor vehicle maintenance and repair shops.

The first code letter represents the 'normal friction coefficient,' determined by averaging four points on the second fade curve in SAE brake material test method J661 ("Chase Machine"), measured at $200,250,300$ and $400^{\circ} \mathrm{F}$. The second is called the 'hot friction coefficient.' It averages 10 experimentally-determined points from the same test: 400 and $300^{\circ} \mathrm{F}$ on the first fade recovery; $450,500,550,600$, and $650^{\circ} \mathrm{F}$ on the second fade segment; and 500, 400, and $300^{\circ} \mathrm{F}$ on the second recovery segment. Additional qualifications are given in SAE J866a.

SAE Recommended Practice J866a lists the following codes and associated friction coefficients:

\begin{tabular}{|c|c|}
\hline Code & Friction Coefficient \\
\hline C & 10.15 \\
\hline D & $>0.15$ but $\leq 0.25$ \\
\hline E & $>0.25$ but $\leq 0.35$ \\
\hline F & $>0.35$ but $\leq 0.45$ \\
\hline G & $>0.45$ but $\leq 0.55$ \\
\hline H & $>0.55$ \\
\hline Z & underclassified \\
\hline
\end{tabular}

In recent years, the value of edge codes has become controversial in light of the growing recognition that brake frictional response, and the apparent friction coefficient, are dependent not only on the material composition, but also on the environment, the mechanics of the system, and the duty cycles to which the brakes are subjected.

According to commercial literature there are significant limitations regarding the use of SAE edge codes: 
1) Test specimens on the Chase Machine are 1" square pads and do not represent full-sized brake pads. Many, if not most, brake engineers believe that full-sized brake (inertial) dynamometer tests represent a better method for characterizing brake material response than the Chase Machine.

2) The edge code gives no indication of wear resistance.

3) Edge codes cannot and should not be used as the sole selection criterion for a replacement brake material.

\section{$\underline{4.2}$ Friction Brake Compositions for Aircraft and Ground Vehicles}

The history of brake materials shows that some of the simplest compositions (fiber plus resin) can be effective, but there have been all kinds of commercial additives introduced and promoted. The ratio of resin to carbon to metallic fibers in semi-metallic brake materials has changed very little during the $20^{\text {th }}$ century [27:30:43 $+/$ - about $1 \%$ ); ref. Nicholson (1995)]. On the other hand, there are at least six types of resins alone. The reasons for so many additives are partly based on function but also on ingredient cost, availability, and processing issues, the latter including mixture blending, dimensional stability, and pre-forming capability. Nicholson (1995) reports that the same ingredients can be sent to several plants and the resulting brakes can have friction coefficients that vary by over a factor of 2 . Therefore, friction brake composition is only a part of the picture in ensuring satisfactory brake performance.

It is worthwhile comparing some typical compositions of aircraft brakes with those of automotive and truck brakes because there is a certain amount of overlap in their functional requirements.

\subsection{Aircraft Brake Formulations}

Information in this section was compiled from several sources, Three notable sources, listed in 4.3 below, are (1) N. Murdie (2000), (2) Y. T. Tatarzicki and R. T. Webb (1992), and (3) N.A. Hooton (1969).

Aircraft brakes primarily consist of resin/steel, metallic linings, and carbon-carbon (C-C) combinations. The $\mathrm{C}-\mathrm{C}$ combinations are more commonly used in high-performance brakes due to their high-temperature characteristics. For example, commercial aircraft, like the Airbus 319, MD-11, Boeing 767, and 777, use C-C brakes. Military aircraft, like the F-15E, F-18, F-22, and Joint Strike Fighter use C-C brakes. A number of varieties of carbon and C compounds are used as matrix materials in aircraft brakes: (1) resin, (2) coal tar/synthetic pitch, (3) petroleum pitch, and (4) pyrolytic carbon. These sometimes contain additives to adjust friction, temperature characteristics, and mechanical properties. Carbon materials can be characterized as graphitic or non-graphitic. Processing and heat treatment affects the degree of graphitization. Generally, as the disc heat treatment temperature increases, the degree of graphitization increases. Graphitizable C includes pitch, chemical vapor deposited C, and meso-phase pitch. So-called non-graphitizable carbon includes the resins and 'PAN'-based material. 
Starting materials for C-C brake discs include polyacrylonitrile (PAN), pitch, and mesophase Pitch. PAN produces $\mathrm{C}$ fiber material with somewhat lower modulus, lower density, but somewhat higher strength. Pitch materials have higher modulus, lower strength, higher density, and higher thermal conductivity. By adjusting the form and composition of fibers and matrices, a wide variety of properties can be produced in the $\mathrm{C}-\mathrm{C}$ materials. Pitch tends to cost more than PAN.

C fibers generally exhibit varying degrees of property anistropy. For example, heat transport is generally much higher longitudinally than transverse to the fiber axis. Therefore some $\mathrm{C}-\mathrm{C}$ discs are made with fine-scale needle-like fibers oriented perpendicular to the plane of the disc to enhance heat flow. These needles are perpendicular to another structural matte (woven layer) of fibers that lies parallel to the disc face.

Antioxidants help protect the $\mathrm{C}-\mathrm{C}$ discs from reacting with the environment when they frictionally heat. An example is a phosphate coating of $\mathrm{Al}, \mathrm{Zn}$, or $\mathrm{Mn}$ that is brushed on the edges of the brake discs and then 'charred.' The antioxidants are kept away from the rubbing surfaces of the discs because they can reduce friction.

The ability of the materials to stand up under rejected take-off (RTO) conditions is another important requirement. In that case, 10-40 million ft-lbs of work must be dissipated in 20-25 seconds (e.g., 0.75-0.9 MJ/kg for a commercial aircraft). There is interest in applying C-C materials to heavy trucks. $\mathrm{C}-\mathrm{C}$ brakes have been tested on cars and racing vehicles. The friction coefficient for $\mathrm{C}-\mathrm{C}$ varies significantly with interface temperature; therefore, braking performance varies under low and high-energy braking conditions.

In addition to friction and wear behavior, the following properties are reported to be important in C-C composite brakes:
(1) density
(5) tensile strength
(2) porosity
(6) flexural strength
(3) thermal conductivity
(4) specific heat
(7) compressive strength
(8) shear strength

(9) impact strength

Selected, reported compositions of aircraft brake materials follow. Where descriptions are vague, like "friction dust" or "metals/oxides," the compositions are proprietary. Even listing an element like "Fe" is a vague reference because there are many forms and sizes available (fibers, powder, sponge, etc.). Rarely, if ever, are the exact compositions and constituents of friction materials known by other than the producer.

\subsubsection{Hooton (1969)}

\begin{tabular}{|c|c|c|c|}
\hline \multicolumn{4}{|c|}{ Aircraft brake Material "A" used against steel } \\
\hline Function & Material & Amount & Comments \\
\hline Matrix & $\mathrm{Cu}$ & 31 vol \% & \\
\hline Friction producer & mullite & 22 vol. $\%$ & \\
\hline Antioxidant & graphite & 32 vol. \% & \\
\hline
\end{tabular}




\begin{tabular}{|c|c|c|c|}
\hline \multicolumn{4}{|c|}{ Aircraft brake Material " $\mathrm{B}$ " used against steel } \\
\hline Function & Material & Amount & Comments \\
\hline Matrix & $\mathrm{Cu}-\mathrm{Fe}$ & 34 vol. \% & \\
\hline Friction producer & mullite-silica & 42 vol. \% & \\
\hline Antioxidant & graphite & 22 vol. \% & \\
\hline Friction modifiers & & 2 vol. $\%$ & 1 ingredient \\
\hline
\end{tabular}

\subsubsection{Automotive Brake Pad Formulations}

Automotive and truck brake pads and shoes usually contain a binder, performance modifiers, abrasives, lubricants, and fillers. A representative sample of compositions follows. Some examples list constituents by composition, but other examples are included here to illustrate the kinds of formulations that are specified by using commercial additive products of proprietary composition. Note that in a number of cases, a range of compositions is reported rather than a single value. This was done, at least in part, to conceal the actual compositions of the materials. Therefore, the percentages of the constituents may not add to a total of $100 \%$. Note also that some of the compositions are given in weight percent and others are given in volume percent. Nicholson (1995) asserts that volume percent is the correct unit of measure for friction material composition. The exact compositions of commercial friction materials are almost never published in the open literature.

According to Bush et al. (1972), the average wear rate of a typical automotive brake pad material is $510^{-5} \mathrm{~cm}$ (0.5 micrometers) per brake application. This corresponds to approximately $3 \mathrm{mg}$ of material loss per brake application.

\section{$\underline{4.2 .2 .1}$ Tsane et al. (1985)}

Tsang et al. conducted friction tests of several asbestos-free materials that had the following compositions:

\begin{tabular}{|c|c|c|c|}
\hline \multicolumn{4}{|c|}{ Asbestos-Free Material " $\mathrm{T}$ " } \\
\hline Function & Material & Amount $(w t \%)$ & Comments \\
\hline Binder & resin & $13-18$ & thermoset \\
\hline Fiber reinforcements & fiberglas & $6-24$ & \\
\hline & inorganic fiber & $8-16$ & \\
\hline "friction dust" & & $0-20$ & \\
\hline Elastomer & polymer & $0-20$ & \\
\hline Carbon/graphite & carbon & $1-4$ & \\
\hline Inorganics & & $12-32$ & \\
\hline Metals / oxides & & $0-19$ & \\
\hline Asbestos-Free Materi & & & \\
\hline Function & Material & Amount $(w t \%)$ & Comments \\
\hline Binder & resin & $8-14$ & thermoset \\
\hline Fiber reinforcements & fiberglas & $14-16$ & \\
\hline & inorganic fiber & $10-16$ & \\
\hline "friction dust" & & $0-7$ & \\
\hline Elastomer & polymer & $0-7$ & \\
\hline
\end{tabular}




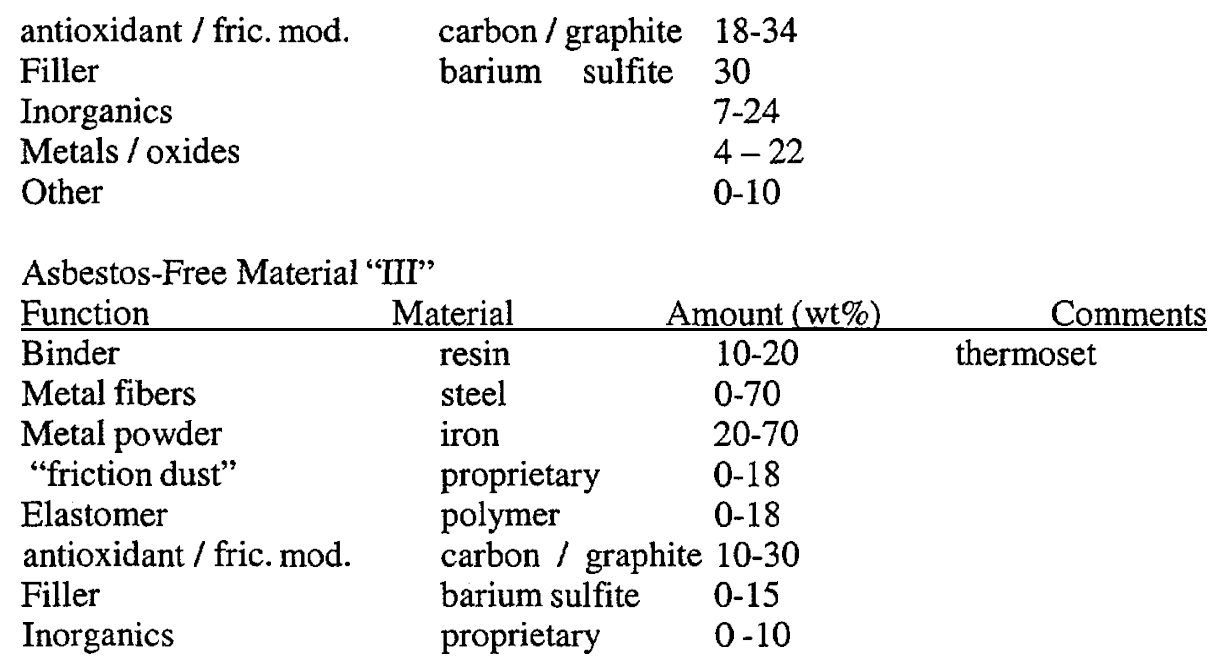

\subsubsection{Jang et al. (2000)}

Experimental composition of pads used against cast iron discs in a series of dynamometer tests of additive effects.

$\begin{array}{llll}\text { Function } & \text { Material } & \text { Amount (vol\%) } & \text { Comments } \\ \text { Binder } & \text { phenolic resin } & 20 & \\ \text { Filler } & \text { aramid pulp } & 6 & \\ & \text { barium sulfate } & 20 & \\ \text { Fiber } & \text { ceramic fiber* } & 3 & \\ \text { Fiber } & \text { Cu fibers } & 3 & \\ \text { Additves - misc. } & \text { calcium hydroxide } 3 & \\ & \text { cashew particles } & 10 & \\ & \text { vermiculite } & 3 & \\ \text { Elastomer } & \text { mica } & 3 & \\ \text { Friction producers/modif. } & \text { rubber } & 3 & \\ & \text { MoS } & 3 & \\ & \text { graphite } & 5 & \\ & \mathrm{Sb}_{2} \mathrm{~S}_{3} & 2-6 & \text { a variable in experiments } \\ & \mathrm{ZrSiO}_{4} & 2-6 & \text { a variable in experiments } \\ & \text { potassium titanate balance } & \end{array}$

\subsubsection{The PQ Corporation Tests}

Six automotive brake pad formulations were used to demonstrate the effectiveness of hollow ceramic microspheres ("Extendospheres FM") in brake performance tests. Product names are used in this list of ingredients to illustrate using commercial additives. The ranges below spanned the six different pad compositions. They were tested in commercial dynamometers against cast iron brake rotors.

\begin{tabular}{lll} 
Material & Amount $(w t \%)$ & Comments \\
\hline Barium sulfite & $29-35$ & \\
Kevlar & $0.71-1.10$ & \\
PMF & $9.9-23.5$ & mineral fiber reinforcement - Sloss Industries \\
Interfibe 230 & $3-3.5$ & \\
Phenolic & $0-10.6$ &
\end{tabular}




$\begin{array}{lll}\text { HRJ } 730 & 0-7.2 & \text { product of Schenectady Chemicals } \\ \text { Reclaimed rubber } & 4-4.7 & \\ \text { Vermiculite } & 4-4.7 & \\ \text { Wollastonite } & 0-11 & \\ \text { Graphite 3226 } & 5-5.9 & \\ \text { Cashew particles } & 3.5-4.4 & \\ \text { Magnesium oxide } & 1.5-1.8 & \\ \text { Ceramic microspheres } & 0-11.8 & \\ \text { Rock wool } & 5-5.9 & \\ \text { HRJ 583 } & 0-7.2 & \text { product of Schenectady Chemicals }\end{array}$

\subsubsection{Sloss Industries Sample Formulations}

An automotive brake pad formulation was used to demonstrate the effectiveness of PMF® reinforcing fibers in brake performance tests. In the first example, the pad material was preformed at $1200 \mathrm{psi}$, hot-pressed at $300^{\circ} \mathrm{F}$ for six minutes at $2000 \mathrm{psi}$, and then post-cured at $400^{\circ} \mathrm{F}$ for eight hours. A proprietary resin composition was used. In the second example, a range of 3 compositions is provided. The third example is for a shoe/drum type brake shoe material.

\begin{tabular}{ll}
$\begin{array}{l}\text { Example 1: } \\
\text { Material }\end{array}$ & Composition_(wt\%) \\
\hline Barytes & 37.3 \\
SP 60-18 resin & 20.3 \\
Cashews & 4.0 \\
Graphite & 6.8 \\
Rubber & 6.2 \\
Aramid fiber & 2.8 \\
PMF fibers & 22.6
\end{tabular}

Example 2 - Range in compositions for three different pads.

\begin{tabular}{lc} 
Material & Range in Com \\
\hline Barytes & $21-22.5$ \\
FRJ-774 resin & 14 \\
PMF fiber 204 & 20 \\
Graphite & $0-2$ \\
Talc & $8-10$ \\
Steel fibers & 10 \\
Brass chips & $0-2$ \\
Vermiculite & $12.5-15$ \\
Kevlar pulp & 1.5 \\
HRJ-2354 friction modifier & $5-9$
\end{tabular}

\subsubsection{Chapman et al. (1999)}

Pads were fabricated by reactive metal infiltration. They were tested against cast iron in a FAST (friction assessment and screening test) configuration (flat pad-on-disc at constant drag). No fade was observed, and $\mu$ was in the range of $0.3-0.45$. 


$\begin{array}{lclc}\text { Function } & \text { Material } & \text { Amount } & \text { Comments } \\ \text { Base material } & \text { aluminum } & \text { not given } & \\ \text { Reinforcing particles } & \mathrm{B}_{4} \mathrm{C} & \text { not given } & \text { bi-modal particle size distribution (75 } \mu \mathrm{m} \text { to } \\ & & & <1.0 \mu \mathrm{m} \text {, vol. fraction } \sim 0.48-0.72)\end{array}$

\subsubsection{Eriksson et al. (2000)}

The typical composition of a Volvo 850 brake pad material was given as follows:

\begin{tabular}{llcc} 
Function & Material & Comount $(w t \%)$ & Conts \\
\hline Matrix & binder material & 8 \\
& other & 11 \\
Fillers & clay and iron oxide & 8 \\
Fibers & steel, aramid, glass & 30 \\
Friction modifiers & brass/bronze & 15 \\
& graphite & 15 \\
& metal sulphides & 8 \\
Abrasives & quartz & 5
\end{tabular}

\subsubsection{Wirth and Whitaker (1992)}

Studies of the composition of transfer films were performed on brake pads of this composition sliding on gray cast iron.

\begin{tabular}{llcc} 
Function & Material & Amount (vol.\%) & Comments \\
\hline Matrix & resin & 40.0 & \\
Fillers & vermiculite & 20.0 & \\
& barytes & $30-38$ & \\
Fibers & steel & 0 or 5 \\
Friction modifiers & molybdenum disulphide 0 or 2 \\
& lead sulphide & 0 or 5
\end{tabular}

\subsubsection{Gudmand-Hover et al. (1999)}

The effects of solid lubricants on disc brake behavior were investigated using a dynamometer. Volvo standard, unventilated rear brake discs were used. Conditions for test type 1: 600 stops from $50 \mathrm{~km} / \mathrm{h}$ at 30 bars pressure and $70^{\circ} \mathrm{C}$. Conditions for test type 2: 350 stops from $120 \mathrm{~km} / \mathrm{h}$ at 40 bars pressure and $200^{\circ} \mathrm{C}$. Friction films were formed under test 2 conditions. Under test 1 conditions, the solid lubricant additives had no significant effects.

$\begin{array}{llrl}\text { Function } & \text { Material } & \text { Amount }(\mathrm{vol} \%) & \text { Comments } \\ \text { Matrix } & \text { resin and rubber } & 23-26 & \\ \text { Fillers } & \text { barytes, friction dust } & & \\ & \text { and vermiculite } & 25.5-41 & \\ \text { brass } & 0 \text { or } 5 & \\ \text { Fibers } & \text { aramid } & 0 \text { or } 9 & \\ \text { Friction modifiers } & \text { metal sulphides } & 8 & \mathrm{Cu}, \mathrm{Pb}, \text { or Sb sulphides } \\ \text { Abrasives } & \text { zirconia } & 0 \text { or } 5 & \\ & \text { alumina } & 0 \text { or } 5 & \end{array}$




\subsubsection{Handa and Kato (1996)}

Authors investigated the effects of $\mathrm{Cu}$ powder, barium sulphate, and cashew dust on friction and wear of friction materials against cast iron. A sub-scale flat pad-on-disc arrangement was used. Conditions: 25 braking applications, $588 \mathrm{~N}$ (on $350 \mathrm{~mm}^{2}$ area $\Rightarrow 1.68 \mathrm{MPa}$ contact'pressure), 5.6 $\mathrm{m} / \mathrm{s}$ engagement speed. Fade effects decreased when the barium sulphate was removed, but wear rate greatly increased. Regression analysis predicted lowest friction for high cashew content, but low $\mathrm{Cu}$ and barium sulphate content. Maps of $\mathrm{Cu}$, barite, and cashew composition versus friction and wear were calculated.

\begin{tabular}{llrr} 
Function & Material & Amount $(v 01 \%)$ & Comments \\
\hline Matrix & phenolic resin & 20 & \\
Fillers & barium sulphate & $30-0,0-40,20$ & ranges for three series of tests \\
& cashew dust & $30,40-0,40-0$ & ranges for three series of tests \\
Fibers & aramid & 20 & \\
Metal & Cu powder & $0-30,0-40,20$ & ranges for three series of tests
\end{tabular}

\subsubsection{Howell and Ball (1995)}

Authors compared the friction and wear of an aluminum/SiC composite with that of cast iron against three pad materials. A modified drilling stand was used with a contact pressure of 1.034 $\mathrm{MPa}$ and sliding speeds of 0.52 to $3.16 \mathrm{~m} / \mathrm{s}$. The following pad compositions were reported. Friction and wear results were mixed, depending on material combination and severity of test conditions.

\begin{tabular}{llccc} 
Function & Material & $\begin{array}{c}\text { Organic pad } \\
(\text { wt } \%)\end{array}$ & $\begin{array}{c}\text { Semi-met pad A } \\
\text { (wt\%) }\end{array}$ & $\begin{array}{c}\text { Semi-met pad B } \\
\text { (wt\%) }\end{array}$ \\
\hline Binder & phenolic resin & 43 & 25 & 16 \\
Fibers & organic fiber & 20 & & \\
Metal & Cu & 0.6 & 15 & 15 \\
& $\mathrm{Fe}$ & & 43 & 3 \\
& $\mathrm{Al}$ & 15 & 7 & .4 \\
Lubricant & graphite & & & 5 \\
Abrasive & alumina & 2 & 5 & 52 \\
Filler & rubber & 15 & & 3 \\
& paper & 4.4 & 2 &
\end{tabular}

\subsubsection{Kato and Soutome (2001)}

Stochastic methods were used in an attempt to formulate brake pads. A subscale pad-on-disc tester was used to generate friction and wear data on the effects of each component. The standard disc material was cast iron. There were ten potential components in the pad material. The 'optimized' composition for the combination of highest friction coefficient $(\mu=0.38)$ and lowest wear rate was as follows:

$\begin{array}{llcl}\text { Function } & \text { Material } & \text { Amount (vol \%) } & \text { Comments } \\ \text { Matrix } & \text { phenolic resin } & 25.0 & \\ \text { Fillers } & \text { barium sulphate } & 0.02 & \\ & \text { cashew dust } & 19.4 & \\ & \text { calcium carbonate } & 0.0 \quad \text { studied, but not in the optimal composition }\end{array}$




$\begin{array}{llr}\text { Fibers } & \text { aramid } & 3.0 \\ & \text { ceramic } & 15.0 \\ \text { Metal } & \text { Cu powder } & 20.0 \\ \text { Abrasive } & \text { alumina } & 10.0 \\ \text { Lubricant } & \text { graphite } & 7.3 \\ & \text { molybdenum disulphide } & 0.0 \quad \text { studied, but not in the optimal composition }\end{array}$

Summary. The compositions of commercial and experimental pad materials varied widely, although some constituents were common to nearly all of them. Typical ranges of the more common constituents are as follows:

\begin{tabular}{|l|c|c|}
\hline \multicolumn{1}{|c|}{ Constituent } & $\begin{array}{c}\text { Range } \\
\text { (vol\%) }\end{array}$ & $\begin{array}{c}\text { Typical value } \\
\text { (vol\%) }\end{array}$ \\
\hline \hline phenolic resin & $10-45$ & $20-25$ \\
\hline barium sulphate & $0-40$ & $20-25$ \\
\hline fibers & $5-30$ & - \\
\hline cashew particles & $3-30$ & $15-20$ \\
\hline graphite & $0-15$ & $5-7$ \\
\hline metal suphides & $0-8$ & $0-5$ \\
\hline abrasives & $0-10$ & $2-3$ \\
\hline "friction dust" & $0-20$ & - \\
\hline
\end{tabular}

As mentioned in 3.3, "friction dust" is an ambiguous term, yet it is used in describing many brake pad formulations. It is likely that friction dust actually contains some of the elements and compounds mentioned previously under other categories, like fillers and lubricants. Sometimes, however, the term 'friction dust' is used to describe brake and clutch additives that are based on cashew particles.

\subsubsection{Passenger Car and Truck Brake Disc and Drum Materials}

\subsubsection{Cast Iron.}

Automotive and truck discs and drums are typically produced using gray (also spelled grey) cast iron with Type A graphite (flakes having a uniform distribution and random orientation) with a pearlitic matrix of low ferrite and carbide content. Several of the typical cast iron grades used for brake materials and their $\mathrm{C}$ and $\mathrm{Si}$ contents are given in the following table. Data were obtained from the ASM Handbook, Vol. 1, 1990, ASM International, Materials Park, Ohio:

\begin{tabular}{|l|c|c|c|}
\hline \multicolumn{1}{|c|}{ Application } & Grade & $\begin{array}{c}\text { Carbon Content } \\
\text { (total carbon in wt\%) }\end{array}$ & $\begin{array}{c}\text { Silicon Content } \\
\text { (wt\%) }\end{array}$ \\
\hline \hline light-duty brake drums & 2500 & $3.20-3.50$ & $2.0-2.4$ \\
\hline moderate service drums & $2500 \mathrm{a}$ & $3.40 \mathrm{~min}$ & $1.6-2.1$ \\
\hline medium duty brake drums & 3000 & $3.10-3.40$ & $1.9-2.3$ \\
\hline $\begin{array}{l}\text { heavy-duty drums requiring } \\
\text { resistance to heat checking }\end{array}$ & $3500 \mathrm{~b}$ & $3.40 \mathrm{~min}$ & $1.3-1.8$ \\
\hline
\end{tabular}




\begin{tabular}{|l|l|l|l|}
\hline extra heavy-duty drums & $3500 \mathrm{c}$ & $3.50 \mathrm{~min}$ & $1.3-1.8$ \\
\hline
\end{tabular}

Wear of gray cast iron in brake applications occurs by abrasive, adhesive and oxidative processes and cannot generally be represented by an Arhenius type relationship. According to Anderson (1992), typical specific wear rates for cast iron drums are the order of $0.2-1 \mathrm{mg} / \mathrm{MJ}[1.6-8.0 \mathrm{x}$ $10^{-5} \mathrm{in}^{3} / \mathrm{hp}$-hr], but rates as high as $5-16 \mathrm{mg} / \mathrm{MJ}$ can result when the lining material is very abrasive.

\subsubsection{Aluminum-Based Metal Matrix Composites.}

There has been interest in using aluminum-based metal matrix composites (MMCs) for brake disc and drum materials in recent years. While much lighter than cast-iron, they are not as resistant to high temperatures and are sometimes only 'used on the rear axles of automobiles because the energy dissipation requirements are not as severe compared with the front axle. Therefore, from a performance standpoint - especially' as regards long drags with excessive temperature buildup - there are serious performance issues with Al-MMCs. It was originally thought that reductions in brake noise and consumer warranty-related complaints would decrease with Al-MMCs, but this has not proven to be the case.

Commercial literature from Duralcan (1993) provides the following comparison of properties between Al MMCs with gray cast iron:

\begin{tabular}{|c|c|c|c|c|}
\hline Property & Units & $\begin{array}{c}\text { Al-MMC } \\
\text { Type F3S.20S-T61 }\end{array}$ & $\begin{array}{c}\text { Al-MMC } \\
\text { Type F3D20S-T5 }\end{array}$ & $\begin{array}{c}\text { Gray dast Iron } \\
\text { Grade 30/35 }\end{array}$ \\
\hline \hline Elastic modulus & $\mathrm{Msi}$ & 14.3 & 16.5 & $13.0-17.2$ \\
\hline Yield strength & $\mathrm{ksi}$ & 49 & 57 & $31-39$ \\
\hline Density & $\mathrm{Ib} / \mathrm{in}^{3}$ & 0.0999 & 0.1019 & 0.257 \\
\hline Thermal conductivity & $\mathrm{BTU} / \mathrm{ft} \mathrm{hr}{ }^{\circ} \mathrm{F}$ & 105. & 85.5 & 27.3 \\
\hline Specific heat & $\mathrm{BTU} / \mathrm{b}$ oF & 0.200 & 0.198 & 0.096 \\
\hline $\begin{array}{c}\text { Thermal expansion } \\
\text { coefficient }\end{array}$ & $\left(10^{6} / \mathrm{OF}^{\circ}\right)$ & 9.7 & 9.4 & 6.8 \\
\hline
\end{tabular}

Howell and Ball (1995) compared the sliding wear of Al-MMC and cast iron disc materials against an organic and three semi-metallic pad materials. Tests were done on a modified vertical drilling machine with a torque cell mounted on the base. While the friction and wear of the AlMMC were high at high speeds and loads, the behavior could be greatly improved, even beyond that of cast iron discs, given the correct match of pad and disc material. Organic pads were a better match for the AI-MMC than semi-metallic pads.

Oda et al. (1997) evaluated the wear of Al-MMC rotors containing various amounts of SiC. The base alloy was Al-10Si-Mg. Particles of SiC less than about $12 \mu \mathrm{m}$ in size were dispersed by stirring them into the molten alloy. It was found that the temperature limitation for use was about $450^{\circ} \mathrm{C}$. Above that temperature, there was excessive scoring. 
Aluminum/boron carbide composites have shown promising friction and wear behavior as a candidate disc material using the Chase test [Chapman et al. (1999); see section 5.2 for a description of the Chase machine]. Specimens were produced by reactive metal infiltration.

Overall, the future for using Al-MMC materials for discs is not clear. While they reduce weight, they tend to be more expensive than conventional gray cast iron and have not shown distinct performance advantages.

\subsubsection{Carbon and Ceramic Brakes}

Carbon-carbon brakes with ceramic additives have been developed by Brembo S.p.A (Curno, Italy). Having a density of $2.2-2.4 \mathrm{~g} / \mathrm{cm}^{3}$, they offer the advantage of light weight, and the manufacturer claims they exhibit uniform frictional behavior. The 2000 model year Porsche offers premium ceramic brakes (trade name - SIGRASIC, by SGL GmbH) as an option, but cost is high. There is also interest in using aircraft brake technology as a basis for new automotive and truck brake materials, but a major challenge is in ensuring that the frictional performance remains stable over a range of operating temperatures. Materials development efforts are underway in this area.

\subsection{Brake Material Test Methods and Apparatus}

A number of materials tests (compression tests, hardness, thermal conductivity measurements, etc.) are employed during the development of brake materials and additives, but the final qualification test for brake materials involves extensive on-vehicle tests with full-sized components. Brake performance is affected not only by the materials and vehicle hardware design, but also significantly by driver behavior, the vehicle usage, the state of adjustment of the brake hardware, and the overall environment in which the vehicle is driven. Add to these considerations the possible influences of braking control systems, engine braking, and the aerodynamics in the wheel well, and no laboratory test can simulate driving conditions precisely.

To reduce preliminary material qualification costs and to facilitate research, a variety of laboratory-scale test machines have been developed. These range from massive, inertial dynamometers with electronic controls and sensors to small, rub-shoe machines that can sit on a bench-top. Some off-vehicle test systems involve instrumented skid pads onto which a fullyloaded vehicle can drive and apply the brakes. Instrumented roll-on-type systems can test one set of vehicle axles at a time. The amount of data obtained from this wide range of tests varies greatly, and friction data from one type of brake test may not directly correlate with that from another type. Added to this concern is the fact that many of the larger dynamometer units are custom, one-of-a-kind units. Therefore, data for different materials are usually ranked in relative terms within the confines of the given test method, and can agree between one method and another.

The following summarizes the various levels of brake material testing:

I. Vehicle Road Tests 

II. Vehicle Skid-Pad Tests
III. Vehicle Drive-on Dynamometers (in-ground or portable)
IV. Inertial Dynamometers (full-scale hardware)
V. Inertial Dynamometers (sub-scale hardware)
VI. Laboratory Tribometers

Off-vehicle brake material test methods (IV-VI) range from simple drag tests at constant speed and contact pressure, to complex, multi-stage qualification tests involving programmed changes in contact pressure, speed, temperature, and repetitive contacts that simulate vehicle braking events (e.g., SAE J 1652).

The following subsections describe several common laboratory-scale friction material testing machines. The basic elements include a means to apply a force, use of conformal contact, and a means to measure frictional torque. Some tests involve constant speed, but others involve deceleration. Use of multiple load applications is common, as is temperature measurement.

\subsection{The FAST Machine}

The Friction Assessment and Screening Test (FAST) machine was introduced in the mid-1960's by Ford Motor Company as a quality assurance test. It uses small block specimens, about 6.35 $\mathrm{mm}$ square, dragging on the circumference of a test ring at constant torque (actuator pressure is adjusted to maintain torque) for 90 minutes. Some investigators have attempted to use this to evaluate new materials for vehicles, but it was only intended as a quality assurance tool for brake materials, not as a development tool. According to some reports, the FAST machine does not replicate road conditions well enough to be used in brake materials R\&D.

According to Nicholson (1995), higher friction materials that contain more abrasive additives tend to clean the ring specimen and produce steadier results on the FAST machine than on the Chase machine, described subsequently. However, the relatively high pressures generated during FAST tests (due to the small contact area of the block) can produce significant evidence for fade that is not observed during more realistic types of tests, like inertial dynamometer brake tests.

\subsection{The Chase Machine}

The Chase Machine is used to perform SAE test J661a and was involved in the development of edge codes. It consists of a rotating drum with a $25.4 \mathrm{~mm}$ square pad of friction material loaded against the inner diameter of the drum (279.4 mm ID) by an air pressure system. Friction and wear data can be obtained. The wear is usually reported in terms of weight loss of the pad and thickness loss for the drum. A comparison of Chase Machine data for several material combinations with that from an inertial dynamometer was reported by Tsang et al. (1985). The test results from the two machines were inconsistent. 


\section{$\underline{5.3 \text { Other Sub-Scale Testing; Machines }}$}

Sub-scale testing machines, other than inertial dynamometers have been designed for use in brake materials research. Such machines are usually custom-built, one-of-a-kind units. Depending on the focus of the research, they can be instrumented for torque (friction), temperature, and vibrational measurements. While not duplicating every aspect of on-vehicle braking, they can be used to study fundamental responses of materials to braking-like levels of energy input under carefully-controlled conditions. Phenomena like fade, thermo-elastic instability ('hot-spots'), pad wear, and friction-induced film formation can be studied using subscale testing machines.

Depending on the type of brake phenomena under investigation (e.g., noise, vibration, friction level, thermo-elastic effects, etc.) good correlations may or may not exist between sub-scale and full-scale tests, like inertial dynamometer tests. For certain studies, however, sub-scale machines constitute a cost-effective tool for brake materials developers. For example, when the amount of experimental materials is limited or when the fabrication costs for full-scale prototypes possessing a range of material compositions is prohibitively expensive, sub-scale tests can provide enough screening information to down-select the most promising candidates.

\section{$\underline{5.4 \text { Inertial Dynamometers and FMVSS Tests }}$}

Inertial dynamometers use one or more shaft-mounted weights to store a given amount of energy which must then be dissipated by the brake materials during testing. Such machines vary in size from laboratory-scale, sub-size units to huge, full-size units that can test aircraft and heavy truck brake components.

Federal Motor Vehicle Safety Standard (FMVSS) tests for brake materials require full-size inertial dynamometers. FMVSS 121 identify three main characteristics: effectiveness, fade, and recovery. Effectiveness measures the efficiency of braking under different line pressures. Fade refers to the ability to decelerate quickly time after time (10 applications) without the need to exert unduly high line pressure. Recovery involves 20 stops at lesser rates of acceleration under a maximum allowed line pressure of 85 psi. FMVSS 135, scheduled to have taken effect in 2000 , is an attempt to harmonize US standards with international automotive brake tests.

\subsection{Reference\&}

A. E. Anderson (1980) "Wear of Brake Materials," in Wear Control Handbook, ASME, pp. 843-857.

A. E. Anderson (1992) "Friction and Wear of Automotive Brakes," in ASM Handbook, Friction Lubrication and Wear Technology, Volume 18, ASM International, Materials Park, Ohio, pp. 569577.

Borden Packing and Industrial Products, Inc. (1994) Literature on modified resin products, Louisville, KY. 
H. D. Bush, D. M. Rowson, and S. E. Warren (1972) "The Application of Neutron Activation Analysis to the Measurement of the Wear of a Friction Material," Wear, 20, pp. 21 1-225.

BBU Chemie (1993) "Friction Additives," Product literature, Arnoldstein, Germany.

T. R. Chapman, D. E. Niesz, R. T. Fox, and T. Fawcett (1999) "Wear-resistant aluminum-boron-carbide cermets for automotive brake applications," Wear, 236, pp. 81-87.

Duralcan ${ }^{\circledR}$, Alcan Aluminum Ltd. (1993) "Aluminum Composites, The Light Weight, Performance Materials Solution for Automotive Applications," brochure.

M. Eriksson and S. Jacobson (2000) "Tribological surfaces of organic brake pads," Tribol. Intern., 33, pp. 817-827.

K.-C. Gong, Y. C. Cheng, and Y.-Y. Huang (1985) "The High temperature Resistance of Polymeric Brake Composites," ASME Wear of Materials Conference Proc., ASME, New York, pp. 765-770.

L. Gudmand-Hoyer, A. Bach, G. T. Neilsen, and Per Morgan (1999) "Tribological properties of automotive disc brakes with solid lubricants," Wear, 232, pp. 168-175.

Y. Handa and T. Kato (1996) "Effects of Cu Powder, BaS04, and Cashew Dust on the Wear and Friction Characteristics of Automotive Brakes," Tribology Trans., 39, pp. 246-353.

Hoeganaes Corp. (1990) "Friction Powder Grades," Product literature, River-ton, NJ.

N. A. Hooton (1969) "Metal-Ceramic Composites in High-Energy Friction Applications," Bendix Technical Journal, Spring 1969, pp. 55-61. (concerning aircraft brakes)

G. J. Howell and A. Ball (1995) "Dry sliding wear of particulate-reinforced aluminum alloys against automobile friction materials," Wear, 181-183; pp. 379-390.

H. Jang and S. J. Kim (2000) "The effects of antimony trisulfide and zirconium silicate in the automotive, brake friction material on friction characteristics," Wear, 239, pp. 229-236.

T. Kato and H. Soutome (2001) "Friction Material Design for Brake Pads Using Database," Tribology Transactions, 44, pp. 137-141.

N. Murdie (2000) "The Use of Carbon-Carbon Composites in Aircraft Braking Applications," Honeywell (GE) Aircraft Landing Systems, South bend, IN, in-house lecture at ORNL on October 24, 2000.

G. Nicholson (1995) Facts About Friction, P\&W Price Enterprises, Inc., Croydon, PA.

N. Oda, Y. Sugimoto, T. Higuchi, and K. Minesita (1997) "Development of Disk Brake Rotor Utilizing Aluminum Metal Matrix Composite,” Soc. of Auto. Engr., paper 970787, 5 pp.

PQ Corporation (1993) Extendospheres ${ }^{\circledR}$ product literature, Valley Force, PA.

S. K. Rhee (1970) “Wear Equation for Polymers Sliding Against Metal Surfaces,” Wear, 16, pp. 43 1445. 
S. K. Rhee (1971) 'Wear of Metal-Reinforced Phenolic Resins,” Wear, 18, pp. 471-477.

S. K. Rhee (1974) "Wear Mechanisms for Asbestos-Reinforced Automotive Friction Materials," Wear, 29, pp. 391-393.

Sloss Industries Corp. (no year) "PMF® Fiber - The Preferred Reinforcement in Friction Products," product literature, Birmingham, AL.

R. T. Spurr (1972) "Fillers in Friction Materials," Wear, 22, pp. 367-409.

Y. T. Tatarzicki and R. T. Webb (1992) "Friction and Wear of Aircraft Brakes," ASM Handbook, Vol. 18, ASM International, Materials Park, Ohio, pp. 582-587

P. H. S. Tsang, M. G. Jacko, and S. K. Rhee (1985) "Comparison of Chase and Inertia Brake Dynamometer Testing of Automotive Friction Materials," ASME Wear of Materials, pp. 129-137.

M. Weintraub (1998), Brake additives consultant. Private communication.

A. Wirth and R. Whitaker (1992) "An energy dispersive X-ray and imaging X-ray photoelectronc spectroscopical study of transfer film chemistry and its influence on friction coefficient, " J. Phys. D. -Applied Phys., pp. A38 - A43. 


\section{Appendix Thermophysical Properties of Selected Materials}


Appendix

Thermophysical Properties of Selected Materials

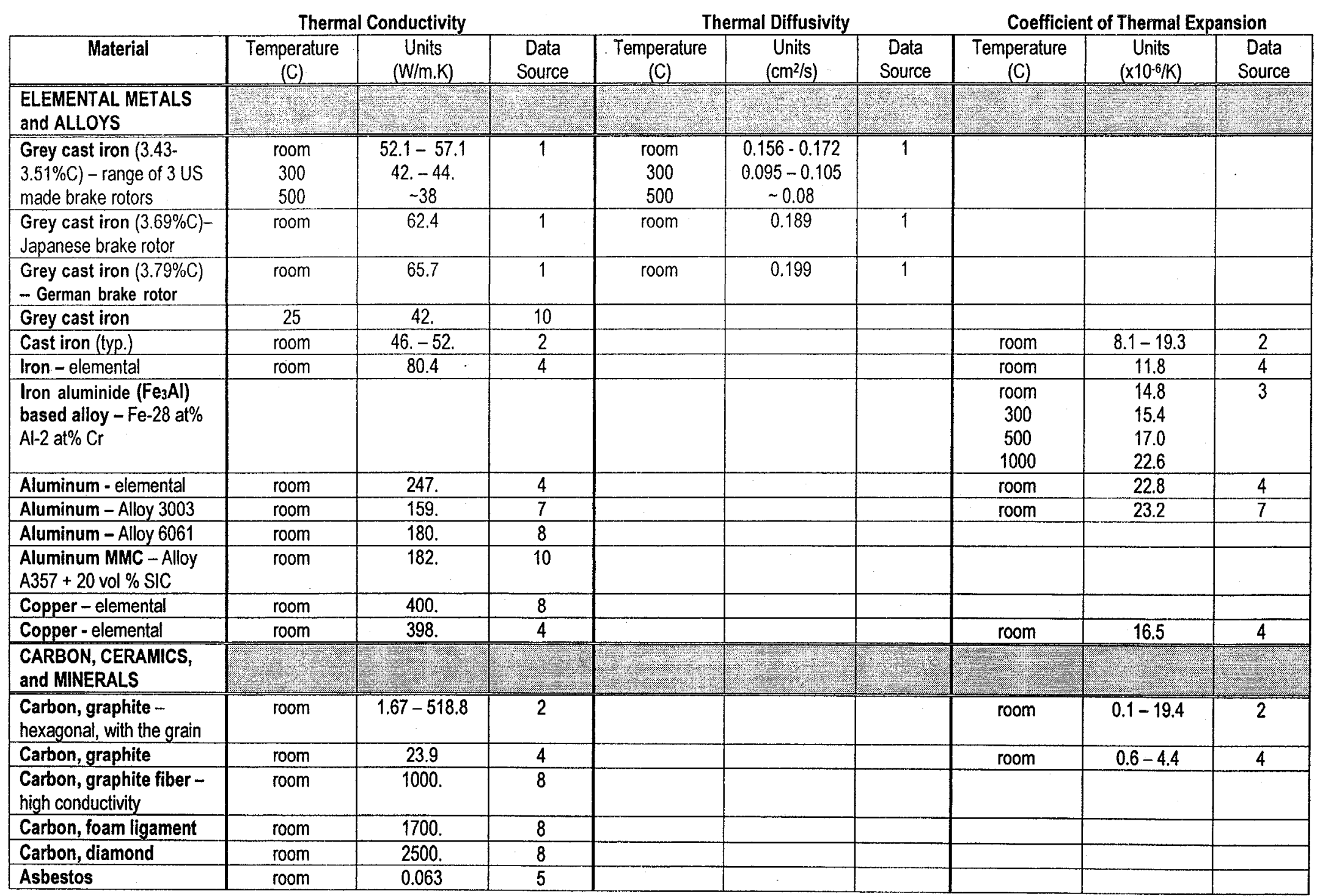


Appendix - Continued

\begin{tabular}{|c|c|c|c|c|c|c|c|c|c|}
\hline Asbestos - building board & room & $0.04-0.16$ & 9 & & & & & & \\
\hline Material & $\begin{array}{l}\text { Temperature } \\
\text { (C) }\end{array}$ & $\begin{array}{l}\text { Thermal } \\
\text { Conductivity } \\
(\text { W/m.K })\end{array}$ & $\begin{array}{l}\text { Data } \\
\text { Source }\end{array}$ & $\begin{array}{c}\text { Temperature } \\
\text { (C) }\end{array}$ & $\begin{array}{l}\text { Thermal } \\
\text { Diffusivity } \\
\left(\mathrm{cm}^{2} / \mathrm{s}\right)\end{array}$ & $\begin{array}{l}\text { Data } \\
\text { Source }\end{array}$ & $\begin{array}{c}\text { Temperature } \\
\text { (C) }\end{array}$ & $\begin{array}{l}\text { Coeff. of } \\
\text { Thermal Exp. } \\
\left(\times 10^{-6} / \mathrm{K}\right)\end{array}$ & $\begin{array}{c}\text { Data } \\
\text { Source }\end{array}$ \\
\hline $\begin{array}{l}\text { CARBON, CERAMICS, } \\
\text { and MINERALS } \\
\text { (continued) }\end{array}$ & 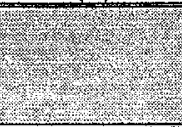 & $\begin{array}{ll} \\
\end{array}$ & 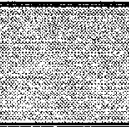 & & 3. & 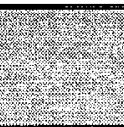 & (2) & (3) & 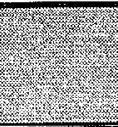 \\
\hline Silicon - elemental & room & 156. & 4 & & & & room & 2.62 & 4 \\
\hline Silica sand - dry & room & 0.33 & 5 & & & & & & \\
\hline Glass wool & room & 0.04 & 9 & & & & & & \\
\hline $\begin{array}{l}\text { Silicon carbide - } \\
\text { hexagonal, sintered }\end{array}$ & 127 & $63 .-155$ & 2 & & & & room & $4.3-5.6$ & 2 \\
\hline $\begin{array}{l}\text { Silicon carbide - cubic, } \\
\text { CVD }\end{array}$ & $\begin{array}{c}127 \\
1327\end{array}$ & $\begin{array}{l}121 . \\
34.6\end{array}$ & 2 & & & & room & 5.5 & 2 \\
\hline $\begin{array}{l}\text { Silicon nitride - Type NT- } \\
451\end{array}$ & $\begin{array}{c}30 \\
400 \\
600\end{array}$ & $\begin{array}{l}19.8 \\
15.2 \\
14.6\end{array}$ & 6 & $\begin{array}{c}30 \\
400 \\
600\end{array}$ & $\begin{array}{l}0.087 \\
0.045 \\
0.040\end{array}$ & 6 & $\begin{array}{l}200 \\
400 \\
600\end{array}$ & $\begin{array}{l}2.0 \\
2.4 \\
2.7\end{array}$ & 6 \\
\hline $\begin{array}{l}\text { Aluminum oxide - } \\
\text { hexagonal }\end{array}$ & $\begin{array}{c}127 \\
1127\end{array}$ & $\begin{array}{c}27.2 \\
5.8\end{array}$ & 2 & & & & room & $7.2-8.6$ & 2 \\
\hline $\begin{array}{l}\text { Boron nitride - } \\
\text { compacted }\end{array}$ & room & 18.0 & 5 & & & & & & \\
\hline $\begin{array}{l}\text { Zirconium oxide - } \\
\text { partially stabilized }\end{array}$ & room & $1.8-2.2$ & 2 & & & & room & $8.9-10.6$ & 2 \\
\hline Mica & room & 0.43 & 5 & & & & & & \\
\hline Quartz & room & 1.38 & 5 & & & & & & \\
\hline Rock wool & room & $0.04-0.06$ & 9 & & & & & & \\
\hline Soapstone (talc) & room & 1.63 & 5 & & & & & & \\
\hline $\begin{array}{l}\text { POLYMERIC and } \\
\text { ELASTOMERIC } \\
\text { MATERIALS }\end{array}$ & & & $\sqrt{3} \cdot$ & 4 & & 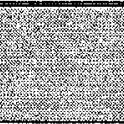 & 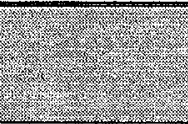 & & \\
\hline Phenolic resin - cast & room & 0.16 & 5 & & & & & & \\
\hline Rubber - synthetic & room & 0.14 & 5 & & & & & & \\
\hline Rubber - silicone & room & 0.22 & 5 & & & & & & \\
\hline Teflon & room & 0.25 & 5 & & & & & & \\
\hline
\end{tabular}

Note: Ref's. 5 and 9 data were converted from English units to ISO units as follows: $k$ [BTU in $/ \mathrm{hr} \mathrm{ft}^{2}{ }^{\circ} \mathrm{F}$ ] $\times 0.14413=\mathrm{W} / \mathrm{m}-\mathrm{K}$

Data sources follow: 


\section{Appendix - Continued}

1. R. L. Hecht, R. B. Dinwiddie, W. D. Porter, and H. Wang (1996) “Thermal Transport Properties of Grey Cast Irons," Soc. of Automotive Engineers, paper number 962126

2. W. J. Lackey, D. P. Stinton, G. A. Cerny, L. L. Fehrenbacher, and A.C. Schaffhauser (1983) Proc. International Symposium on Ceramic Components for Heat Engines, Hakone, Japan.

3. B. A. Pint, K. L. More, P. F. Tortorelli, W. D. Porter, and I. G. Wright (2000) "Optimizing the Imperfect Oxidation Performance of Iron Aluminides," in Proc. Materials Sci. Forum, in press.

4. Metals Handbook, Desk Edition (1998), ASM International, Materials Park, Ohio.

5. Watlow Corporation, product catalog, St. Louis, MO.

6. Norton Ceramics Company, Data sheet.

7. R. H. Perry and C. H. Chilton (1973) Chemical Engineers handbook, $5^{\text {th }}$ Ed., McGraw-Hill, New York.

8. Collected data from the Carbon Materials Group, Metals and Ceramics Division, Oak Ridge National Laboratory, Oak Ridge, TN.

9. 0. W. Eschbach (1966) Handbook of Engineering Fundamentals, John Wiley \& Sons.

10. G. J. Howell and A. Ball (1995) "Dry sliding wear of particle-reinforced aluminum alloys against automobile friction materials," Wear, Vol. 1813, pp. 379. 390. 
ORNL/TM-2001/64

\section{INTERNAL DISTRIBUTION}

1. Ron Bradley, 4500S, MS-6161

2. Robert Honea, $4500 \mathrm{~N}, \mathrm{MS}-6230$

3. Bill Knee, NTRC, MS-6472

4. Jeff Muhs, 9102, MS-8058

5. Ronald Ott, 4515, MS-6063

6. Richard Ziegler, NTRC, MS-6472

7. Tim Burchell, 4508, MS-6088

8. Ralph Dinwiddie, 4515, MS-6064

9. D. Johnson, 4515, MS-6066

10. Arvid Pasto, 4515, MS-6062

11. Karen More, 45 15, MS-6064

12. Phillip Sklad, 4515, MS-6065

13. Lab Records, 4500 N, MS-625

14. ORNL Central Research Library, 4500N, MS-6191

\section{EXTERNAL DISTRIBUTION}

15. Katsumi Tsukui, Akebono America Inc., 26850 Haggerty Rd, Farmington Hills, MI 48331

16. Leonard Buckman, Buckman Consulting Services, Inc., 2258 Shoreline Drive, Brighton, MI 48114

17. S. Rhee, Honeywell -'Friction Materials, 1746 Thunderbird Rd., Troy, MI 48084

18. Andy Mickus, Honeywell Brake Systems, 3000 20th St NE, Cleveland, TN 37323

19. William Singleton, Honeywell CVS, 901 Cleveland Street, Elyria, OH 44036

20. Allen Born, Alumax Engineered Metal Processes Inc., 2404 Dr. F. E. Wright Dr., Jackson, TN 38305

21. George Fenske, Argonne National Laboratory, 9700 S. Cass Ave., ET/212, Argonne, IL 60439

22. Frank Stodolsky, Argonne National Laboratory, 955 L'Enfant Plaza North, SW Suite 6000, Washington, DC 20024-2168

23. Steve Maxon, Averitt Express, P. 0. Box 100342, Nashville, TN 37224-0342

24. Steve Shaffer, Battelle Columbus Laboratories, 505 King Avenue, Columbus, OH 43201

25. Walt Stringham, Bosch Braking Systems, 401 N. Bendix Drive, South Bend, IN 46634-400 1

26. Russell Armer, Brakepro Inc., 101 Brown Farm Rd., Cartersville, GA 30120

27. Brian Lindsay, Ferodo America Inc., 1 Grizzly Lane, Smithville, TN 37166-2810

28. Steven Wyss, Ferodo America Inc., 1 Grizzly Lane, Smithville, TN 37166 
29. Rena Hecht-Basch, Ford Motor Company - Sci Resch Lab., P. 0. Box 2053 - MD 212, Dearborn, MI 48121-2053

30. Paul Sanders, Ford Motor Company - Sci Resch Lab, P, O. Box 2053 - MD 212, Dearborn, MI 4812 1-2053

31. Alex Lee, GM Corp Eng. Tech Ctr., 1435 Cincinnati St MS/E-521, Dayton, OH 45401

32. Sam Riley, Goodyear Tire \& Rubber Co., P. 0. Box 570, Union City, TN 38281

33. Charles Greening, Greening Testing Labs, 19465 Mt Elliott Ave, Detroit, MI 48234

34. Jay White, Hendrickson International, 2070 Industrial Place, S. E., Canton, OH 44707

35. Phillip Craig, Honewell Adv. Composites, Inc., Diamond State Ind Park, 100 Belleview Rd. Newark, DE 19713

36. Basil Barna, Idaho National Engrg., and Env. Lab., P.O. Box 1625, MS-2209, Idaho Falls, ID 83415-2209

37. Jim Trainor, J. T. Trainor \& Assoc., 8 Rivendell, Shelton, CT 6484

38. Hans Kott, Knott Brake Co., 4930 Chippewa Road, Medina, OH 44256

39. Roy Link, Link Engineering, 43855 Plymouth Oaks Blvd., Plymouth, MI 481702585

40. Arne Anderson, Link Engineering Co., 43855 Plymouth Oaks Blvd., Plymouth, MI 48170

41. Jeff Brown, Link-West, Inc., 561 E. Elliott Rd., Ste. 168, Chandler, AZ 85225

42. W. Kahl, National Transport Research Center, Bldg. 9201-3, MS-8063, Oak Ridge, TN 3783 1-8063

43. Mark Kachmarsky, Mack Trucks, Inc., 2402 Lehigh Parkway South, Allentown, PA 18105

44. Dale Bell, Meritor Automotive Inc., 2135 West Maple Rd., Try, MI 48084

45. Gary Ford, Meritor Automotive Inc., 2135 West Maple Rd., Troy, MI 48084

46. Jim Zucchetto, National Academy of Sciences, 2101 Constitution Ave, NW (Rm HA-270)

Washington, DC 20418

47. John Gemender, Navistar International, 2911 Meyer Rd., Fort Wayne, IN 468011109

48. Ronald Pepoy, Navistar International, P. 0. Box 1109, Ft. Wayne, IN 46801-1 109

49. Joseph Kovach, Parker Hannifin Corporation, 6035 Parkland Blvd, Cleveland, OH 44124-4141

50. Mark Koth, PBR Automotive USA, 10215 Caneel Dr., Knoxville, TN 37931

51. David Mohr, Performance Friction Corp., 83 Carbon Metallic Hwy, Clover, SC 29710-0819

52. Dick Radlinski, Radlinski and Associates, 3143 County Road 154, E. Liberty, OH 43319

53. Kevin Judge, Raybestos Brakes, 4400 Prime Parkway, McHenry, IL 60050

54. Ronald Rogers, Rockwell International Corp., 2135 West Maple Rd., Troy, MI 48084-7 186

55. Yngve Naerheim, Rockwell International Science Center, 1049 Camino Dos Rios, Thousand Oaks, CA 91360 
56. Peter Min, Rockwell Science Center, 1049 Camino Dos Rios, Thousand Oaks, CA 91362

57. Jianmei Pan, Rockwell Science Center, 1049 Camino Dos Rios, Thousand Oaks, CA 91360

58. Peter Filip, Southern Illinois University, Center for Advanced Friction Studies, Carbondale, IL 6290 1-4343

59. Donald Dareing, University of Tennessee, 414 Dougherty Eng. Bldg., Knoxville, TN 37966-2210

60. Carl Mannerfelt, Volvo Trucks North America, Inc., 7900 National Service Road, Greensboro, NC 27402-6115

61. Vinod Vemparala, Wellman Friction Products Co., 920 Lake Road, Medina, OH 44256

62. Richard Wares, U. S. Dept. of Energy, FORS, MS 6A-116, Washington, DC 20585-0121

63. Sidney Diamond, U.S. Department of Energy, EE-33, 1000 Independence Ave., SW, Washington, DC 20585-0121 
